scarce resources, but the benefits in social and financial terms are clear.

We thank Dr T A Whittingham and Mr P J Saunders of the ultrasonics section of the regional medical physics department, Newcastle upon Tyne, whose help was essential; Michael Strachan, former senior medical photographer, and Robert Etherington, senior medical photographer at Sunderland Eye Infirmary for their skilful help; and the ophthalmic surgeons of the Northern region who kindly referred us cases.

\footnotetext{
1 Machemer R, Parel J-M, Buettner H. A new concept for vitreous surgery. 1. Instrumentation. Am f Ophthalmol 1972;73:1-7.

Machemer R. A new concept for vitreous surgery. 2. Surgical technique and complications. Am f Ophthalmol 1972;74:1022-33.

3 Machemer R, Norton EWD. A new concept for vitreous surgery. 3. Indications and results. Am f Ophthalmol 1972;74:1033-56.

4 Charles S. Vitreous microsurgery. London: Williams and Wilkins, 1981.

5 Leaver PK, McLeod D. Rationale and techniques of closed vitrectomy. Trans Ophthalmol Soc UK 1977;97:242-7.

6 Roxburgh STD. Preoperative assessment of diabetic eyes for vitreoretinal surgery. Semin Ophthalmol 1987;2:154-61

7 Passani F, Barco L, Venturi G. Pre-vitrectomy examination of the traumatised eye. In: Hillman JS, Le May MM, eds. Ophthalmic ultrasonography. The Hague: Martinus Nijhoff/W Junk, 1983:121-5.

8 Restori M. McLeod D. Ultrasound in pre-vitrectomy assessment. Trans Ophthalmol Soc UK 1977;97:232-4

9 Green RL. The echographic evaluation of spontaneous vitreous haemorrhage. In: Ossoinig KC, ed. Ophthalmic echography. Dordrecht: Martinus Nijhoff/W Junk, 1987:233-8.

10 Hughes JR, Byrne SF. Detection of posterior ruptures in opaque media. In: Ossoinig KC, ed. Ophthalmic echography. Dordrecht: Martinus Nijhoff/W Ossoinig KC, ed. Oph

1 McLeod D Restori $M$. Ultrasonic examination in severe diabetic eye disease. Br f Ophthalmol 1979;63:533-8.

12 Hasenfratz G. Standardised echography before vitreoretinal surgery. In: Thyssen JM, Hillman JS, Gallinga PE, Cennamo G, eds. Ultrasonography in
}

Ophthalmology II. Dordrecht: Kluwer Academic, 1988. (Documenta Ophthalmologica Proceedings Series 51 .

13 Alberti KGMM, Thomas DJB. The management of diabetes during surgery. Br f Anaesth 1979;51:693-707.

14 Wolf GL, Capuano C, Harting J. Nitrous oxide increases intraocular pressure after intravitreal sulphur hexafluoride injection. Anesthesiology 1983;59 $547-8$

15 Vanacker B, Dekegel D, Dionys J, et al. Changes in intraocular pressure associated with the administration of propofol. Br $\mathcal{F}$ Anaesth 1987;59: 1514-7.

16 Aaberg TM, Abrams GW. Changing indications and techniques for vitrectom in management of complications of diabetic retinopathy. Ophthalmology 1987;94:775-9.

17 Thompson JT, Auer CL, De Bustros S, Michels RG, Rice TA, Glaser BM. Prognostic indicators of success and failure in vitrectomy for diabetic retinopathy. Ophthalmology 1986;93:290-5.

18 Mitchell P. The prevalence of diabetic retinopathy: a study of 1300 diabetics from Newcastle and the Hunter Valley. Aust f Ophthalmol 1980;8:241-6.

19 Scobie IN, MacCuish AC, Barrie T, Green FD, Foulds WS. Seriou retinopathy in a diabetic clinic: prevalence and therapeutic implications. Lancet 1981:i:520-1.

20 Blankenship GW, Machemer R. Long-term diabetic vitrectomy results

21 Grey RHB, Malcolm N, O'Reilly D, Morris A. Ophthalmic survey of a diabetic clinic. 1. Ocular findings. Brf Ophthalmol 1986;70:797-803.

22 Aaberg TM. Results of 100 consecutive vitrectomy procedures. In McPherson A, ed. New and controversial aspects of vitreoretinal surgery. Si Louis: Mosby, 1977:245-9.

23 Ramsay Y, Knobloch WH, Cantrill HC. Timing of vitrectomy for active proliferative diabetic retinopathy. Ophthalmology 1986;93:283-9.

24 De Juan E, Sternberg P, Michels RG, Auer C. Evaluation of vitrectomy in penetrating ocular trauma. Arch Ophthalmol 1984;102:1160-3.

25 Oyakawa RT, Michels RG, Blase WP. Vitrectomy for nondiabetic vitreous hemorrhage. Am f Ophthalmol 1983;96:517-25.

26 Peyman GA, Raichand M, Bennett TO. Management of endophthalmitis with pars plana vitrectomy. Br 7 Ophthalmol 1980;64:472-5.

27 Ficker L, Meredith TA, Wilson LA, Kaplan HJ, Kozarsky AM. Chronic bacterial endophthalmitis. Am $\mathcal{f}$ Ophthalmol 1987;103:745-8.

28 Grey RHB, Morris A. Ophthalmic survey of a diabetic clinic. 11. Requirements for treatment of retinopathy. Br f Ophthalmol 1986;70:804-7.

(Accepted 20 April 1989) Report of 10-year follow-up. Ophthalmology 1985;92:503-6.

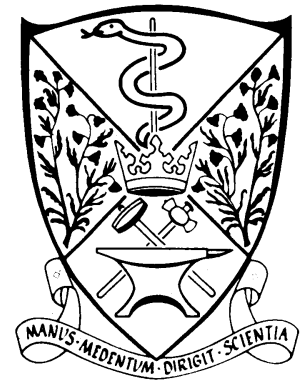

Hammersmith Staff Rounds

\section{The heart in systemic lupus erythematosus}

\section{A cause of myocardial infarction in a man of 20}

\section{History}

March 1982-An 18 year old man presented with a three week history of abdominal distension and swelling of the face and ankles. He did not have a history of risk factors for ischaemic heart disease. He was febrile $\left(38^{\circ} \mathrm{C}\right)$, and the physical findings were of massive leg and sacral oedema, ascites, and a left sided pleural effusion. Table I gives details of the investigations. A chest radiograph showed a left sided pleural effusion. Renal biopsy specimens showed mesangiocapillary glomerulonephritis, and skin biopsy specimens showed deposition of $\operatorname{IgG}$ and complement at the dermoepidermal junction. After immunosuppressive treatment was started his serum albumin concentrations increased to $28 \mathrm{~g} / \mathrm{l}$ and the DNA binding fell to $30 \%$.

December $1982-\mathrm{He}$ presented with acute pleuritic pain in association with a deep venous thrombosis of his right leg. A ventilation-perfusion lung scan showed mismatch strongly suggestive of pulmonary embolism, and he was treated with warfarin. He had a further episode of pleuritic pain six months later.

Fuly 1984-He presented with a five day history of increasing central chest pain. An electrocardiogram showed an acute inferior myocardial infarction. Other investigations showed a creatinine concentration of 95 $\mu \mathrm{mol} / \mathrm{l}$ and a 24 hour urinary protein measurement of $11.9 \mathrm{~g}$. Lupus anticoagulant and anticardiolipin antipodies were present. A coronary angiogram showed hormal coronary arteries, but an echocardiogram showed inferior akinesis. His fasting cholesterol concentration was $8.0 \mathrm{mmol} / \mathrm{l}$. Immunosuppressive treat- ment was continued with azathioprine and prednisolone. He made an uneventful recovery and was free of symptoms with unlimited effort tolerance for the next four years.

August 1988-He presented with a history of central

TABLE I-Results of investigations in man aged 18 presenting with abdominal distension and oedema

\section{Measurement}

\section{Blood pressure}

Proteinuria

Haemoglobin

White cell coun

Platelet count

Erythrocyte sedimentation rate

Direct Coombs' test

Cryoglobin

Blood ure

Creatinine clearance

Serum albumin

Urinary protein excretion

Fasting cholesterol

Prothrombin time

Antithrombin III

Venereal Disease Research Laboratory Test

Trepanoma pallidum haemagglutination test

Complement ${ }^{\star}$ :

C3

$\mathrm{CH} 50$

Antinuclear factor

DNA binding
Partial thromboplastin tim

Lupus anticoagulan

Series edited by:

Dr Robert Winter.

BrMed f 1989;299:245-7 $\star$ Expressed as percentage of normal serum concentrations. $+1 / 160$ Homogenous pattern.

$\ddagger$ Normal $<30 \%$. 
chest pain, and an electrocardiogram taken on admission showed an acute anterolateral myocardial infarction. His blood pressure was $120 / 95 \mathrm{~mm} \mathrm{Hg}$.

Fanuary $1989-\mathrm{He}$ was referred back to this hospital with signs of congestive cardiac failure. Investigations showed an erythrocyte sedimentation rate of $27 \mathrm{~mm}$ in the first hour, blood urea concentration of $6.8 \mathrm{mmol} / \mathrm{l}$, creatinine concentration of $89 \mu \mathrm{mol} / \mathrm{l}$, and creatinine clearance of $1.42 \mathrm{ml} / \mathrm{s}$. Lupus anticoagulant and anticardiolipin antibodies (IgG $39 \mathrm{U} / \mathrm{l}$ (normal $<9 \mathrm{U} / 1)$ and IgM $1.8 \mathrm{U} / 1$ (normal $<8 \mathrm{U} / \mathrm{l}$ )) were present. Table II gives the data from cardiac catheterisation. Coronary angiography showed extensive triple vessel disease (fig 1 ).

\section{Discussion}

Figure 2 shows a summary of the interactions in systemic lupus erythematosus and coronary heart disease.

CMO: We do not know why some patients with active systemic lupus erythematosus develop valvular heart disease while others develop coronary thrombosis. This young man had near normal coronary arteries at presentation and now has appearances that are indistinguishable from those of severe atheroma, though I have little doubt that these lesions were initiated by arteritis and postarteritic thrombotic events.

MJW: The role of antiphospholipid antibodies in the pathogenesis of cardiac lesions is of great interest. We have previously presented on the staff round a patient with severe aortic regurgitation who had anticardiolipin antibodies but did not have any other clinical features or autoantibodies to allow the diagnosis of systemic lupus erythematosus. Such patients have been labelled as suffering from the "primary antiphospholipid syndrome." The prevalence of clinically important cardiac valvular lesions in these patients has been estimated to be as high as $18 \% .^{.}$Several reports have associated these lesions with the presence of antiphospholipid antibodies. ${ }^{2-4}$ Whether there is a causal link between antiphospholipid antibodies and

TABLE II-Data from cardiac catheterisation

\begin{tabular}{lc}
\hline Measurement & \\
\hline Pressure (mm Hg): & \\
Right atrium & 8 \\
Right ventricle & $50 / 16$ \\
Main pulmonary artery & $50 / 30$ \\
Pulmonary artery wedge (mean) & 30 \\
Left ventricle & $125 / 30$ \\
Aorta & $120 / 95$ \\
Cardiac output $(1 / \mathrm{min})$ & $4 \cdot 77$ \\
Cardiac index $\left(1 / \mathrm{min} / \mathrm{m}^{2}\right)$ & $2 \cdot 51$ \\
\hline
\end{tabular}

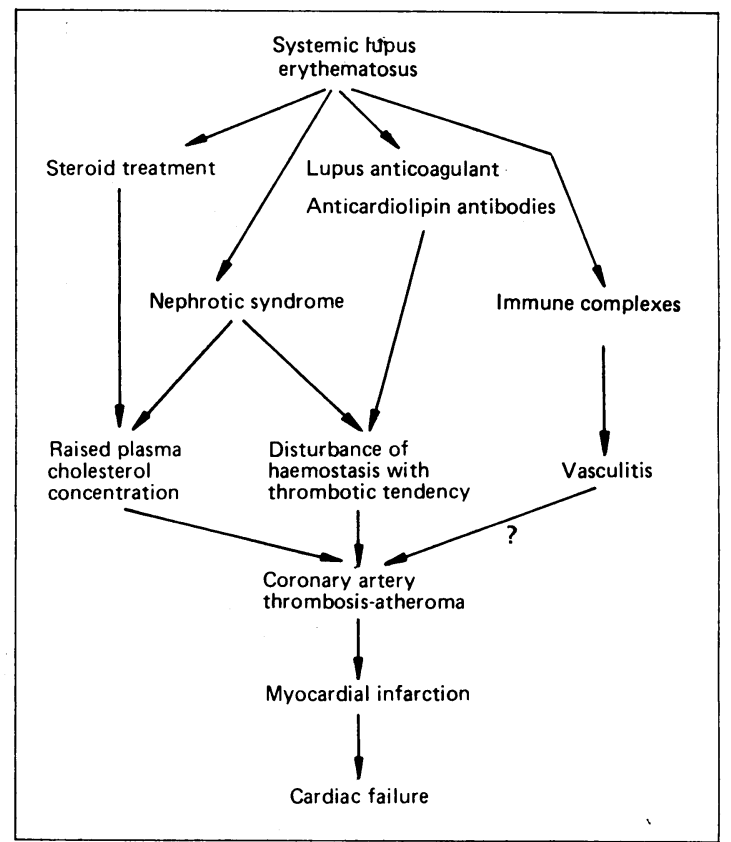

FIG 2-Summary of interactions in pathogenesis of systemic lupus erythematosus and coronary heart disease

valvular damage has not been established. Antiphospholipid antibodies from patients with systemic lupus erythematosus and the primary antiphospholipid syndrome bind predominantly to negatively charged phospholipids, which are ubiquitous on the inner lamella of cell membranes. Whether negatively charged phospholipids are available in vivo for the extracellular binding of these antibodies is uncertain, and no convincing evidence has been presented for such binding. Possibly anticardiolipin antibodies are acting as a marker for another, unidentified, autoantibody that is relevant to the cause of the disease.

The relation of anticardiolipin antibodies to coronary thrombosis is intriguing. There is a raised incidence of myocardial infarction among patients with systemic lupus erythematosus and this is an important cause of death. ${ }^{5}$ It has been attributed to accelerated atherosclerosis in coronary arteries damaged by vasculitis and hyperlipidaemia. The MRL/lpr mouse is an experimental model of systemic lupus erythematosus in which such a train of events seems to occur, though extrapolation from mice to humans is a dubious exercise. High density lipoprotein cholesterol is reduced in patients with active systemic lupus erythematosus, and long term treatment with steroids is associated with raised low density lipoprotein cholesterol and triglyceride concentrations ${ }^{67}$ The changes in
FIG $1-$ Representative coronary angiograms obtained in 1984 (left) and 1988 (right) showing progression of coronary artery disease

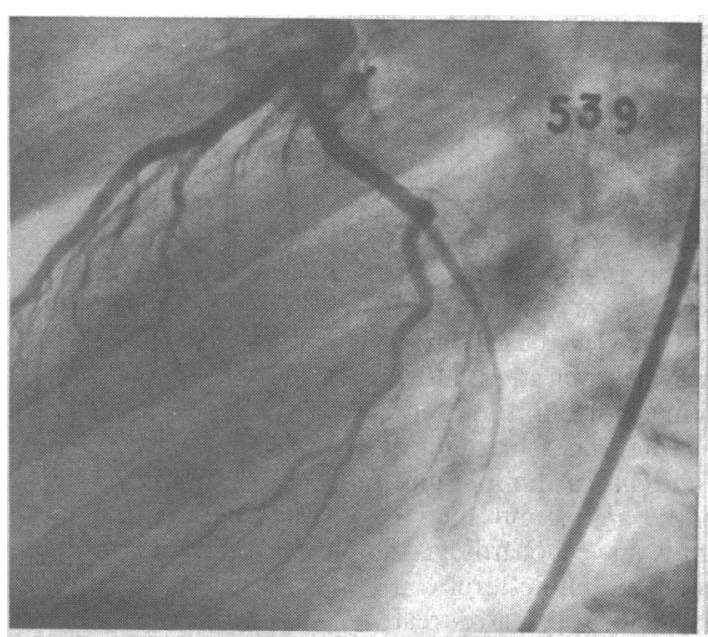


lipids resulting from the nephrotic syndrome may have been an additional risk factor in this patient.

The possible links between anticardiolipin antibodies and myocardial infarction in patients without overt autoimmune disease are controversial. Raised titres of these antibodies have been reported in consecutively ascertained patients with myocardial infarction $^{8}$ and in patients with myocardial ischaemia. ${ }^{9}$ In the study of Hamsten et al, however, the titre of antibodies was low compared with that measured in patients with systemic lupus erythematosus, and whether the antibody or the atherosclerosis came first has not been established.

PN: We have studied 54 consecutive patients with this condition by two dimensional echocardiography with the aim of identifying factors of importance in the pathogenesis of associated heart disease. The abnormalities identified were predominantly of two types: valvular vegetations (principally affecting the mitral valve) and myocardial dysfunction. Patients with raised anticardiolipin antibody titres had a greater incidence of cardiac disease. These were absent in only one patient with systemic lupus erythematosus and Libman-Sacks vegetations on the mitral valve. We have also screened 40 patients with anticardiolipin antibodies but without evidence of systemic lupus erythematosus and found that patients with anticardiolipin antibodies had a high incidence of cardiac abnormalities. Thus, cardiac disease suggested by these abnormalities on two dimensional echocardiography is highly correlated with the presence of high titres of anticardiolipin antibodies without other features of systemic lupus erythematosus.

SRB: The patient had considerable lipid abnormalities. Could you suggest the importance of these in the development of his accelerated coronary artery disease?

GRT: Possibly the sequence of events was as follows. The thrombotic tendency associated with systemic lupus erythematosus was almost certainly responsible for the patient's first myocardial infarct, when his angiogram was normal. The hyperlipidaemia that accompanied his nephrotic syndrome during 1984-8, however, must have been a major additional factor in the development of the triple vessel disease that culminated in his second myocardial infarct. If this patient were presenting today the drug of first choice to treat the hyperlipidaemia would be a hydroxy-3methylglutaryl coenzyme A reductase inhibitor such as lovastatin. Our experience and that of others ${ }^{1011}$ is that such drugs are highly effective in reducing raised low density lipoprotein cholesterol concentrations in the nephrotic syndrome.

SRB: The patient has triple vessel disease and a poorly functioning myocardium. Is cardiac transplantation feasible?

$\mathrm{CMO}$ : His cardiac failure is at present well controlled by an angiotensin converting enzyme inhibitor and diuretic treatment. Transplantation is, however, an important treatment option here and needs to be considered seriously despite anxiety about recurrence of the primary disease in the transplanted organ due, I think, to the risk of recurrent vasculitis.

AJR: Experience of renal transplantation in patients with systemic lupus erythematosus shows that recurrence does occur but that the incidence is rather low. It would therefore seem entirely reasonable to consider cardiac transplantation in this patient.

1 Galve E, Candell-Riera J, Pigrau C, Permanyer-Miralda G, Garcia-DelCastillo H, Soler-Soler J. Prevalence, morphologic types, and evolution of cardiac valvular disease in systemic lupus erythematosus. $N$ Engl $\mathcal{F ~ M e d ~}$ 1988;318:817-23

2 Chartash EK, Paget SA, Lockshin MD. Lupus anticoagulant associated with aortic and mitral valve insufficiency [Abstract]. Arthritis Rheum 1986;29:S95.

3 Cronin ME, Biswas RM, Van der Straeton C, Fleisher TA. IgG and IgM anticardiolipin antibodies in patients with lupus with anticardiolipin anticardiolipin antibodies in patients with lupus with anticardich
antibody associated clinical syndromes. I Rheumatol 1988;15:795-8.

4 Asherson RA, Gibson DG, Evans DW, Baguley E, Hughes GRV. Diagnostic and therapeutic problems in two patients with antiphospholipid antibodies, and therapeutic problems in two patients with antiphospholipid antibodies, heart value

5 Urowitz MB, Bookman AAM, Koehler BE, Gordon DA, Smythe HA, Ogryzlo MA. The bimodal mortality of systemic lupus erythematosus. Am F Med 1976;60:221-5.

6 Ettinger WH, Goldberg AP, Applebaum-Bowden D, Hazzard WR. Dyslipoproteinemia in systemic lupus erythematosus: effect of corticosteroids. Am F Med 1987;83:503-8.

7 Ilowite NT, Samuel P, Ginzler E, Jacobson MS. Dyslipoproteinemia in pediatric systemic lupus erythematosus. Arthritis Rheum 1988;31:859-63.

8 Hamsten A Norberg R, Bjorkholm M, De Faire U, Holm G. Antibodies to cardiolipin in young survivors of myocardial infarction: an association with cardiolipin in young survivors of myocardial infarction:

9 Klemp P, Cooper RC, Strauss FJ, Jordaan ER, Przybojewski JZ, Nel N. Anti-cardiolipin antibodies in ischaemic heart disease. Clin Exp Immunol Anti-cardiolipin an $1988: 74: 254-7$.

10 Golper TA, Illingworth DR, Bennett W/M. Effective and safe short term improvement in nephrotic hypercholesterolaemia with the HMG CoA improvement in nephrotic hypercholesterolaemia with
reductase inhibitor mevinolin. Kidney Int 1987;31:200.

1 Reabelkink AJ, Hene RJ, Erkelens DW, Joles JA, Koommans HA. Effects of simvastatin and cholestyramine on lipoprotein profile in hyperlipidaemia of nephrotic syndrome. Lancet 1988;ii:1335-8.

\section{ANY QUESTIONS}

Is there a place for corticosteroid administered by depot injections in the treatment of hay fever?

When administered prophylactically corticosteroids are effective in controlling the symptoms of hay fever. For this purpose they may be administered by inhalation, orally, or as intramuscular depot injections. For the symptoms of sneezing, rhinorrhoea, and conjunctivitis the selective $\mathrm{H}_{1}$ antagonists, such as terfenadine, astemizole, and citirizine, are the drugs of choice as these symptoms are mainly caused by allergen triggered release of histamine from the increased number of mast cells that colonise these mucosal surfaces in sensitised subjects during the pollen season. ${ }^{1}$ When severe symptoms are expected treatment should be started before the onset of the pollen season. With increasing symptoms, especially when they include nasal blockage, corticosteroids are indicated. The prophylactic use of topical corticosteroids in the form of aqueous aerosol or pressurised metered dose aerosols (beclomethasone dipropionate, flunisolide) provides good protection for most people. Ideally these should be started regularly, either before the pollen season or when symptoms first appear, and continued throughout the season. Their mechanism(s) of action include the reduction or prevention of mast cell hyperplasia stimulated by the allergen, reduction in basophil and eosinophil infiltration, and their well known antioedema effect. ${ }^{1}$ When administered twice daily in the recommended dose this route of administration of corticosteroid has no effect on the pituitary-adrenal axis.

Depot corticosteroid injections, such as betamethasone dipropionate and methylprednisolone acetate, are also effective in ameliorating the symptoms of hay fever. ${ }^{2}$ To achieve their effects a persistent increase in the plasma concentration of corticosteroid is required and persists for about four weeks. A single injection of depot corticosteroid is approximately equivalent to $7.5 \mathrm{mg}$ of prednisolone daily for three to four weeks. Adrenal suppression is almost certain to occur with depot corticosteroid injections. This also lasts for about four weeks after a single intramuscular injection and up to 12 weeks with two treatments. For this reason patients who have received this form of treatment should carry a "steroid card." Other potential hazards of systemic corticosteroids on electrolyte control, bone metabolism, and growth provide additional reasons for avoiding this form of treatment for hay fever whenever possible.

Their use may be advocated when a combination of inhaled corticosteroids and $\mathrm{H}_{1}$ antagonists fails to control symptoms ${ }^{3}$ and when symptoms will coincide with an important life event-for example, examinations, marriage. ${ }^{+}$Thus, though depot corticosteroid preparations are considerably less expensive and more convenient than the regular use of antihistamines and topical corticosteroids, concern over their systemic side effects is the main reason why their use has fallen out of favour. $-S \mathrm{~T}$ HOLGATE, clinical professor of immunopharmacology, Southampton

1 Holgate ST, Howarth PH. What's new about hay fever? Br Med f 1985;291:1-2.

Pichler WJ, Klint T, Blaser M, et al. Clinical comparison of svstemic methylprednisolone acetate versus topical budesonide in patients with seasonal allergic rhinitis. Allergy 1988;43:87-92.

3 Laursen LC, Faurschou P, Munch EP. Intramuscular betamethasone dipropionate vs topical beclomethasone dipropionate and placebo in hay fever. Allergy 1988;43:420-4. 4 Anonymous. Management of hay fever. Drug Ther Bull 1979;17:45-6. 